\title{
OPTIMALISASI KAPASITAS ENERGI ANGIN DAN MATAHARI DENGAN KONFIGURASI MIKROGRID BERDASARKAN KARAKTERISTIK BEBAN
}

\section{OPTIMIZATION OF WIND AND SOLAR ENERGY CAPACITY WITH MICROGRID CONFIGURATION BASED ON LOAD CHARACTERISTICS}

\author{
${ }^{* 1}$ Dhanis Woro Fittrin Selo Nur Giyatno, Lukman Subekti², Adlan Bagus Pradana ${ }^{3}$, \\ Indriana Nurmawati ${ }^{4}$, dan Indra Wibowo ${ }^{5}$ \\ Departemen Teknik Elektro dan Informatika, \\ Sekolah Vokasi Universitas Gadjah Mada
}

Submitted:22-05-2019; Revised: 30-01-2021; Accepted: 23-07-2021

\begin{abstract}
Diploma III Electrical Technology Study Program is a institutional vocational education institutional in Department of Electrical Engineering and Informatics that aims to produce graduate who are ready to work in operation and maintenance of power system. Since phenomena of scarcity of fossil fuels, study program meet the 2 major problems, namely the limitations of electrical energy for practical lab work and increased job skills on the electrical energy conversion of electrical energy from renewable energy. The purpose of this research is to optimalize capacity of solar and wind energy contained in the environment of the laboratory on the microgrid configuration, namely PV-Wind turbine-Battery. Software HOMER is used to simulate microgrid configuration with AC-DC load, AC load, and DC load. The results show indicate that microgrid PV-Wind turbine-Battery is more economically to meet the need AC-DC load than the others.
\end{abstract}

Keywords: Electrical Energy Load; Microgrid; Solar Energy; Vocational Educational; Wind energy.

\begin{abstract}
ABSTRAK
Program Studi Diploma III Teknologi Listrik merupakan institusi pendidikan vokasional di lingkungan Departemen Teknik Elektro dan Informatika yang bertujuan untuk menghasilkan lulusan yang siap bekerja sebagai pelaksana lapangan di bidang operasi dan pemeliharaan sistem tenaga listrik. Seiring dengan kelangkaan bahan bakar fosil, program studi mengalami 2 masalah utama, yaitu keterbatasan energi listrik untuk kebutuhan praktikum dan peningkatan keterampilan kerja pada konversi energi listrik dari energi terbarukan menjadi energi listrik. Penelitian ini bertujuan untuk mengoptimalisasikan kapasitas energi angin dan matahari yang terdapat di lingkungan laboratorium pada konfigurasi mikrogrid PV-Turbin angin-Baterai. Optimalisasi dilakukan dengan simulasi dengan perangkat lunak HOMER. Jenis konfigurasi mikrogrid yang disimulasikan adalah mikrogrid untuk memenuhi beban AC-DC, beban AC, dan beban DC. Hasil simulasi menunjukkan bahwa konfigurasi mikrogrid untuk memenuhi kebutuhan beban AC-DC lebih ekonomis daripada konfigurasi mikrogrid untuk memenuhi kebutuhan beban AC atau DC.
\end{abstract}

Kata Kunci: Beban Energi Listrik; Energi Angin; Energi Matahari; Mikrogrid; Pendidikan Vokasional.

${ }^{*}$ Corresponding author: dhanisworo@ugm.ac.id

Copyright @2021 THE AUTHOR(S). This article is distributed under a Creative Commons Attribution-Share Alike 4.0 International license. Jurnal Teknosains is published by the Graduate School of Universitas Gadjah Mada. 


\section{DHANIS WORO FITTRIN SELO NUR GIYATNO, LUKMAN SUBEKTI, DAN ADLAN BAGUS PRADANA * OPTIMALISASI KAPASITAS ENERGI ANGIN DAN ...}

\section{PENGANTAR}

Program Studi Diploma III Teknologi Listrik merupakan salah satu program studi di lingkungan Departemen Teknik Elektro dan Informatika, Sekolah Vokasi UGM yang bertujuan untuk menghasilkan lulusan yang siap bekerja di bidang operasi dan pemeliharaan sistem tenaga listrik [1]. Seiring dengan kelangkaan bahan bakar fosil yang menjadi sumber energi pembangkit listrik maka Program Studi Diploma III Teknologi Listrik menemui dua masalah, yaitu perlunya sumber energi listrik sebagai modal utama praktikum dan perlunya menyiapkan materi pembelajaran dan/atau keterampilan kerja di bidang konversi energi listrik dengan sumber energi baru. Bahan bakar fosil merupakan sumber energi primer di Indonesia [2]. Hal tersebut disebabkan karena bahan bakar tersebut digunakan sebagai sumber energi bagi sebagian besar pembangkit di Indonesia [3]. Selanjutnya, untuk mengatasi kondisi tersebut, pemerintah melalui Kementerian Energi dan Sumber Daya Mineral - Pekerjaan Umum merencanakan program pembauran energi terbarukan seperti energi air, energi angin, energi matahari, energi panas bumi dan energi panas bumi ke dalam sumber energi listrik baru tersebut [4].

Berdasarkan letak astronomisnya, Indonesia berada di wilayah garis khatulistiwa sehingga Indonesia mempunyai potensi untuk memanfaatkan energi angin [5] dan energi matahari [6]. Pemanfaatan energi angin dan matahari telah banyak dilakukan untuk berbagai keperluan. Referensi [7] menjelaskan produksi metanol dan energi listrik dengan atau tanpa menggunakan energi angin dan matahari. Analisis kelayakan teknik dan ekonomi digunakan untuk mengevaluasi kedua teknologi tersebut. Lokasi elektrolisis menentukan kehandalan penggunaan kedua jenis energi tersebut. Referensi [8] menjelaskan pembelajaran yang diperoleh dari proyek pembuatan solar home system (SHS) di Sri Lanka dan Indonesia. Berdasarkan wawancara dan observasi lapangan, diperoleh hasil bahwa pemilihan teknologi yang tepat akan menentukan keberhasilan proyek karena masyarakat akan dapat mempromosikan partisipasi komunitas dan kepemilikan, pemasar yang terpercaya, demonstrasi dan aktififitas promosi. Selanjutnya, referensi [9] menjelaskan pengembangan pemanfaatan PV di Australia dan Indonesia yang memasukkan aspek budaya setempat. Pemanfaatan energi angin dan matahari lain dijelaskan pada referensi [10]- [11], [12], [13], [14].

Perangkat lunak Hybrid Optimization of Multiple Energy Resources(HOMER) dariNational Renewable Energy Laboratory (NREL) digunakan untuk optimalisasi konfigurasi mikrogrid. Penelitian [15] menjelaskan penggunaan hibrid energi angin dan matahari untuk memenuhi kebutuhan beban AC dan DC. Hasil penelitian menunjukkan bahwa sistem hibrid lebih ekonomis untuk memenuhi kebutuhan beban DC. Penelitian [16] menjelaskan hasil simulasi pemanfaatan energi angin dan matahari di Mesir. Hasil penelitian menunjukkan bahwa hibridisasi energi angin dan matahari menunjukkan biaya pembangkitan lebih murah daripada PV. Selanjutnya, penelitian [17] melakukan penelitian untuk menentukan konfigurasi hibrid energi angin dan matahari di Propinsi Maharashtra, India. Perencanaan dilakukan untuk pemenuhan kebutuhan energi listrik selama 22 tahun untuk 34 calon lokasi. Penelitian [18] menjelaskan optimalisasi sistem hibrid energi angin dan matahari di Statesboro, Georgia dengan sistem terisolasi atau terkoneksi ke jaringan tenaga listrik. Penelitian [19] menjelaskan proses optimalisasi konfigurasi PV-Turbin angin dengan berbagai macam alternatif perbandingan kapasitas antara PV dan turbin angin. Perangkat lunak HOMER digunakan untuk menghitung produksi energi total, variasi biaya sistem, kelayakan ekonomi dan finansial. Sementara itu, perangkat lunak Retscreen digunakan untuk menghitung periode pengembalian biaya investasi dan internal rate of return (IRR).

Penelitian ini bertujuan untuk mendapatkan konfigurasi mikrogrid yang melibatkan pemanfaatan energi angin dan matahari untuk memenuhi kebutuhan praktikum di Laboratorium Teknik Tenaga Listrik, Program Studi Diploma III Teknologi Listrik UGM. Optimalisasi dilaksanakan dengan membuat 
tiga skenario, yaitu mikrogrid untuk memenuhi kebutuhan beban AC-DC, beban DC, dan beban AC.

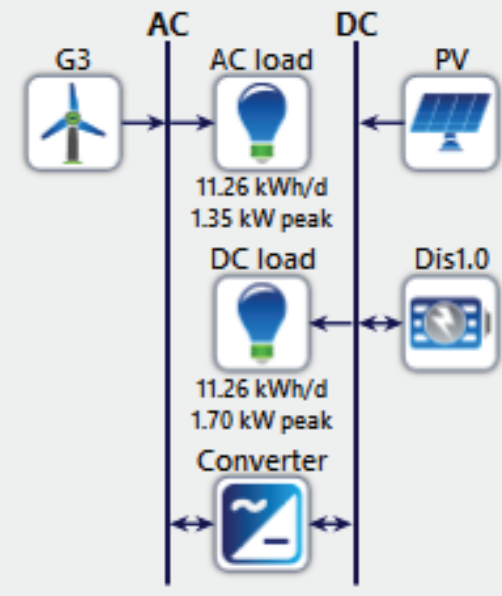

Gambar 1.

Konfigurasi mikrogrid untuk memenuhi kebutuhan beban AC-DC

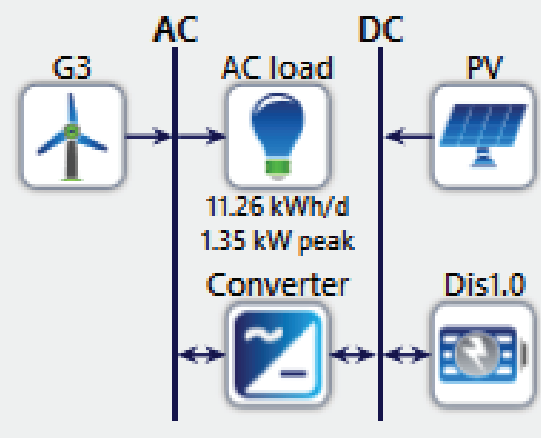

Gambar 2.

Konfigurasi mikrogrid untuk memen uhi kebutuhan beban AC

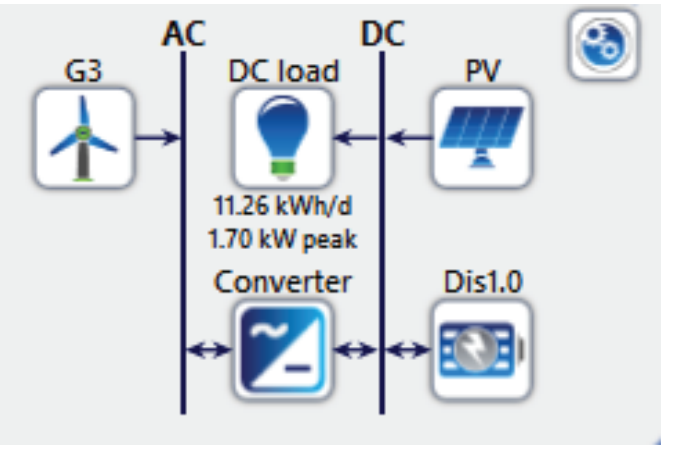

Gambar 3.

Konfigurasi mikrogrid untuk memenuhi kebutuhan beban DC

\section{Metode}

Konsep mikrogrid diusulkan oleh R. H. Lasseter. Dalam konsep tersebut, mikrogrid terdiri atas pembangkit/generator, penyimpan energi, transformer energi, monitoring, proteksi, dan beban. Dengan konsep tersebut, mikrogrid diharapkan dapat melakukan pengontrolan, proteksi, dan manajemen untuk dirinya sendiri termasuk melakukan interkoneksi dengan jaringan tenaga listrik PLN maupun terisolasi [20].

Potensi energi angin dan energi matahari ditentukan oleh letak astronomis dan kondisi di wilayah tersebut. Gambar 4 menunjukkan letak astronomis Laboratorium Teknik Tenaga Listrik, Program Studi Diploma III Teknologi Listrik UGM.

Berdasarkan letak astronomis tersebut, dapat ditentukan potensi energi angin dan matahari. Potensi energi angin dapat diketahui melalui profil kecepatan angin sedangkan potensi energi matahari dapat diketahui melalui profil intensitas sinar matahari seperti pada Gambar 5 dan Gambar 6.

Gambar 5 menunjukkan profil intensitas sinar matahari di lingkungan Laboratorium Teknik Tenaga Listrik. Berdasarkan grafik tersebut, intensitas sinar matahari di wilayah tersebut bernilai $4,80 \mathrm{kWh} / \mathrm{m}^{2} /$ hari. Meskipun demikian, wilayah tersebut mempunyai indeks kecerahan 0,40. Kondisi tersebut menunjukkan bahwa potensi energi matahari di wilayah tersebut hanya $40,00 \%$ yang dapat dikonversi menjadi energi listrik. Hal tersebut disebabkan antara lain oleh kelembaban, temperatur harian dan profil kecepatan angin. Selanjutnya, Gambar 6 menunjukkan profil kecepatan angin di Laboratorium Teknik Tenaga Listrik. Menurut grafik tersebut, kecepatan angin ratarata di lingkungan laboratorium adalah $\pm 4,00$ meter/detik.

Langkah selanjutnya adalah dengan menghitung profil beban. Profil beban dihitung dengan menghitung kebutuhan beban saat jam praktikum (pukul 07.00 WIB - 11.00 WIB dan pukul 12.00 WIB - 16.00 WIB), jam istirahat laboratorium (pukul 05.00 WIB - 07.00 WIB, pukul 11.00 WIB - $12.00 \mathrm{WIB}$, dan pukul 16.00 WIB- 17.00 WIB), dan jam non-operasional 


\section{DHANIS WORO FITTRIN SELO NUR GIYATNO, LUKMAN SUBEKTI, DAN ADLAN BAGUS PRADANA * OPTIMALISASI KAPASITAS ENERGI ANGIN DAN ...}

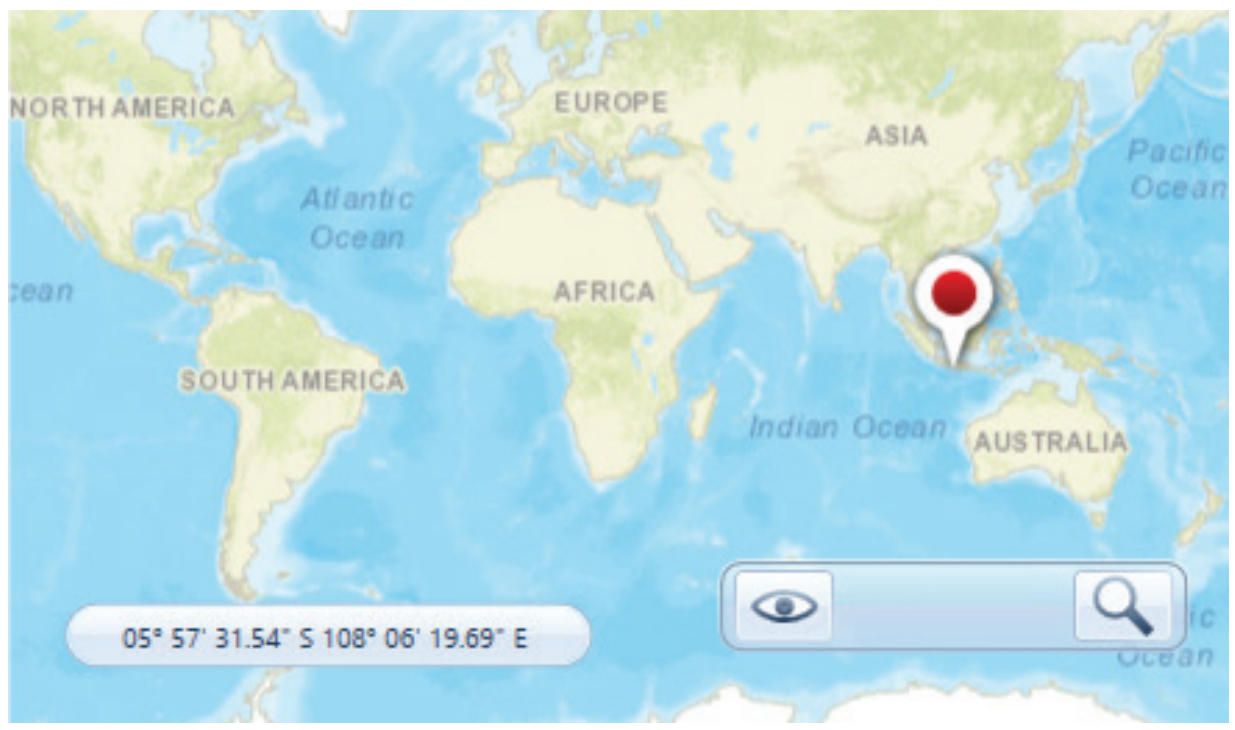

Gambar 4.

Letak astronomis Laboratorium Teknik Tenaga Listrik,

Program Studi Diploma III Teknologi Listrik UGM

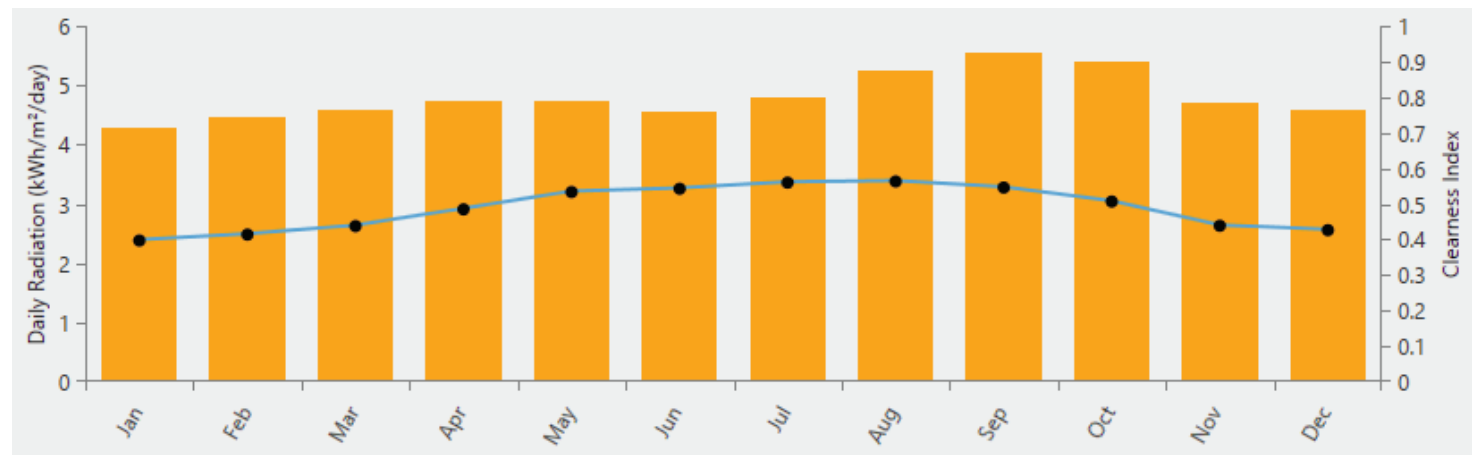

Gambar 5.

Profil intensitas sinar matahari di Laboratorium Teknik Tenaga Listrik, Program Studi Diploma III Teknologi Listrik UGM

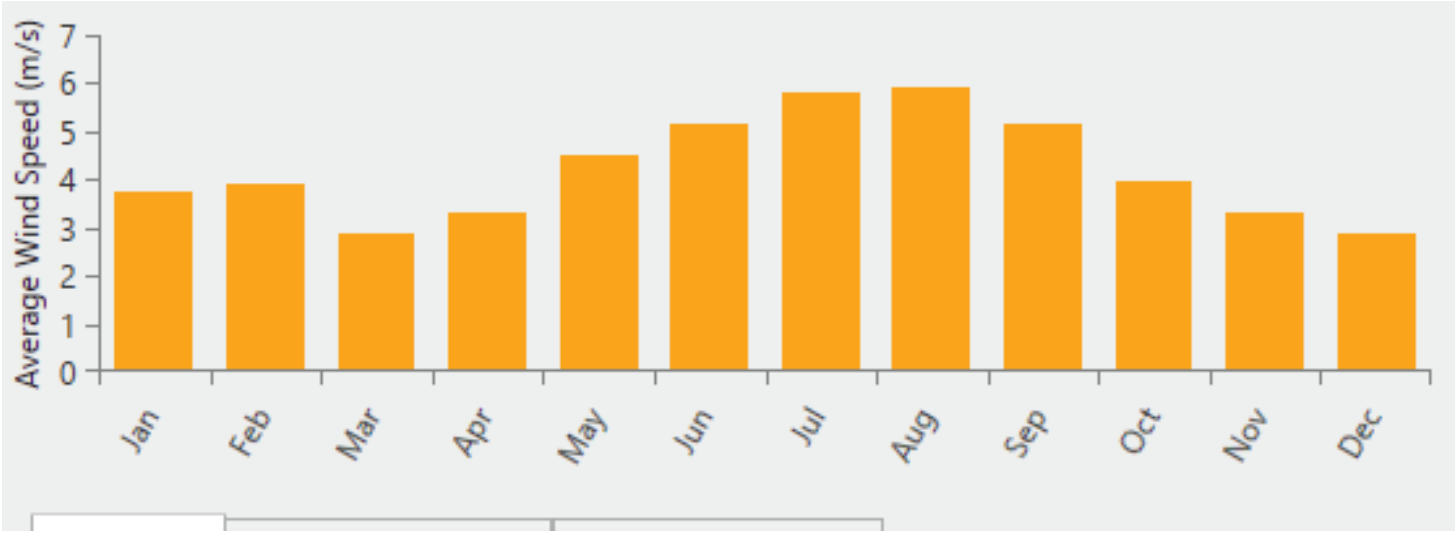

Gambar 6.

Profil kecepatan angin di Laboratorium Teknik Tenaga Listrik, Program Studi Diploma III Teknologi Listrik UGM 
laboratorium (pukul 17.00 WIB - 05.00 WIB dini hari). Setelah menghitung dan memasukkan ke dalam perangkat lunak HOMER maka diperoleh grafik seperti pada Gambar 7, Gambar 8, dan Gambar 9. Profil tahunan beban dibuat dengan toleransi $5,00 \%$ atau toleransi untuk konsep desain untuk diterapkan. Berdasarkan profil beban tersebut, profil beban direncanakan merata sepanjang tahun. Kondisi tersebut didesain dengan asumsi bahwa peralatan digunakan oleh mahasiswa untuk menyusun pembuatan proyek akhir/kegiatan mahasiswa di pergantian semester.
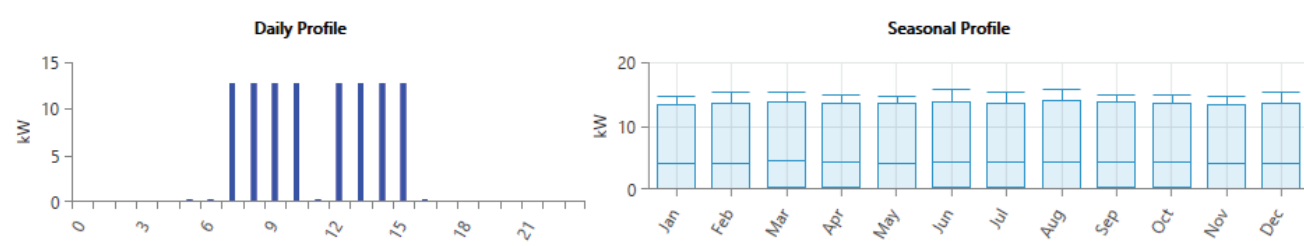

Yearly Profile

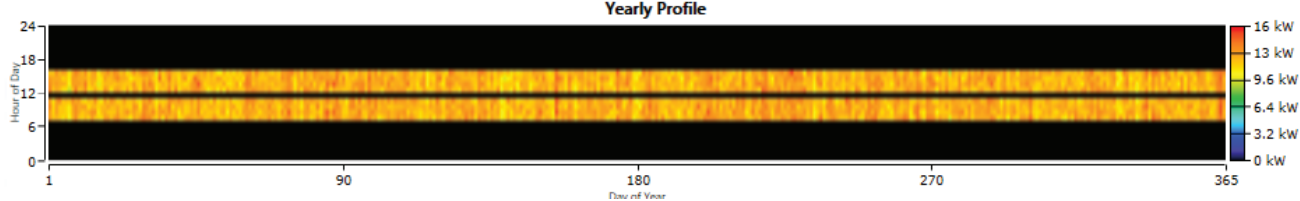

Gambar 7.

Profil beban AC \& DC harian, musiman, dan tahunan di Laboratorium Teknik Tenaga Listrik, Program Studi Diploma III Teknologi Listrik UGM

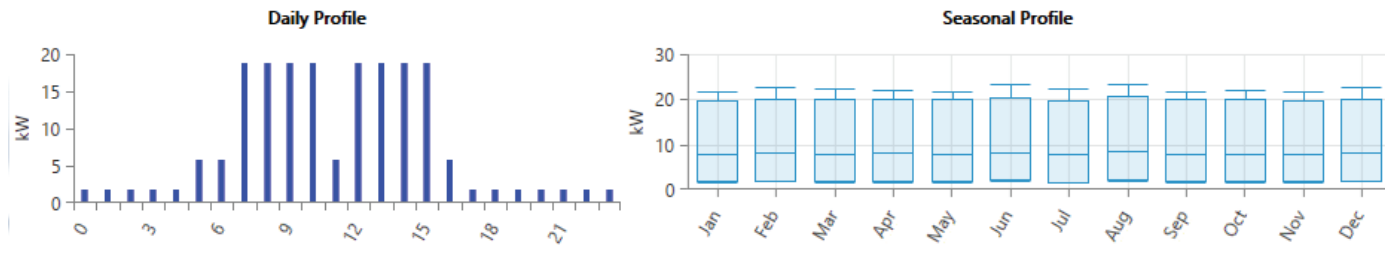

Yearly Profile

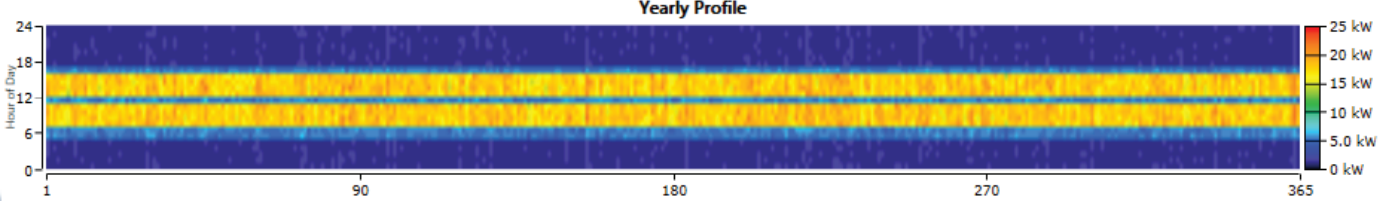

Gambar 8.

Profil beban AC harian, musiman, dan tahunan di Laboratorium Teknik Tenaga Listrik,

Program Studi Diploma III Teknologi Listrik UGM
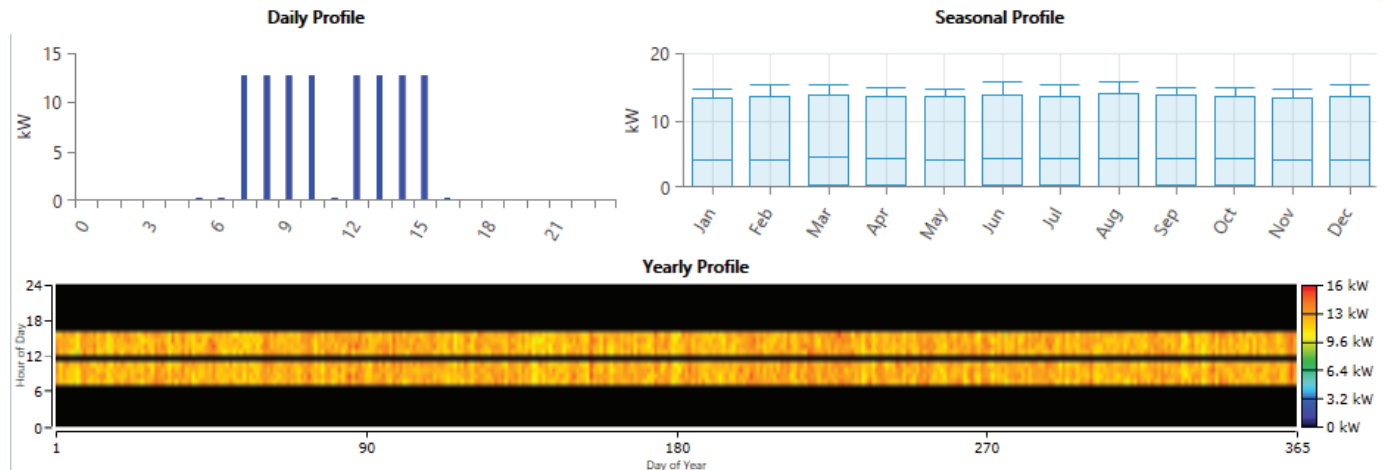

Gambar 9

Profil beban DC harian, musiman, dan tahunan di Laboratorium Teknik Tenaga Listrik, Program Studi Diploma III Teknologi Listrik UGM 


\section{DHANIS WORO FITTRIN SELO NUR GIYATNO, LUKMAN SUBEKTI, DAN ADLAN BAGUS PRADANA \& OPTIMALISASI KAPASITAS ENERGI ANGIN DAN ...}

Tabel 1 berisi batasan kondisi ekonomi yang digunakan sebagai pertimbangan untuk membuat optimalisasi konfigurasi mikrogrid. Pada simulasi ini, faktor lingkungan seperti konsentrasi polutan (karbondioksida, sulfur oksida dan sejenisnya) tidak dimasukkan karena pemerintah belum memberikan insentif pada pemanfaatan energi angin dan matahari di Indonesia.

Tabel 1.

Batasan kondisi ekonomi simulasi dengan perangkat lunak HOMER

\begin{tabular}{l|l|l}
\hline No. & \multicolumn{1}{|c|}{ Variabel } & \multicolumn{1}{c}{ Nilai } \\
\hline 1. & Nominal discount rate & $8,00 \%$ \\
\hline 2. & Expected inflation rate & $2,00 \%$ \\
\hline 3. & Project lifetime & 20 tahun \\
\hline
\end{tabular}

\section{HASIL DAN PEMBAHASAN}

Penelitian ini menghasilkan tiga simulasi konfigurasi mikrogrid PV-Turbin anginBaterai untuk memenuhi kebutuhan beban di Laboratorium Teknik Tenaga Listrik, Program Studi Diploma III Teknologi Listrik, Departemen Teknik Elektro dan Informatika,
Sekolah Vokasi UGM. Pertama, Konfigurasi mikrogrid PV-Turbin angin-Baterai untuk memenuhi kebutuhan beban AC \& DC. Pada simulasi konfigurasi mikrogrid PV-Turbin angin-Baterai untuk memenuhi kebutuhan beban baik beban AC maupun DC diperoleh konfigurasi mikrogrid optimal berupa konfigurasi mikrogrid PV-Baterai dengan biaya pembangkitan energi listrik $\$ 1,12 / \mathrm{kWh}$. Sementara itu, jika menggunakan konfigurasi mikrogrid PV-Turbin angin-Baterai diperlukan biaya pembangkitan energi listrik $\$ 1,30 / \mathrm{kWh}$. Kondisi tersebut ditunjukkan oleh Gambar 10.

Meskipun penggunaan generator turbin angin menyebabkan penurunan penggunaan baterai dan konverter tetapi penambahan generator menyebabkan NPC meningkat menjadi \$123.685. Dengan kondisi tersebut, integrasi generator turbin angin menyebabkan peningkatan biaya pembangkitan energi listrik sebesar $\$ 0,18 / \mathrm{kWh}$. Berdasarkan evaluasi tersebut, untuk memenuhi kebutuhan beban AC \& DC, konfigurasi mikrogrid PV-Baterai lebih ekonomis dibandingkan konfigurasi mikrogrid PV-Turbin angin-Baterai.

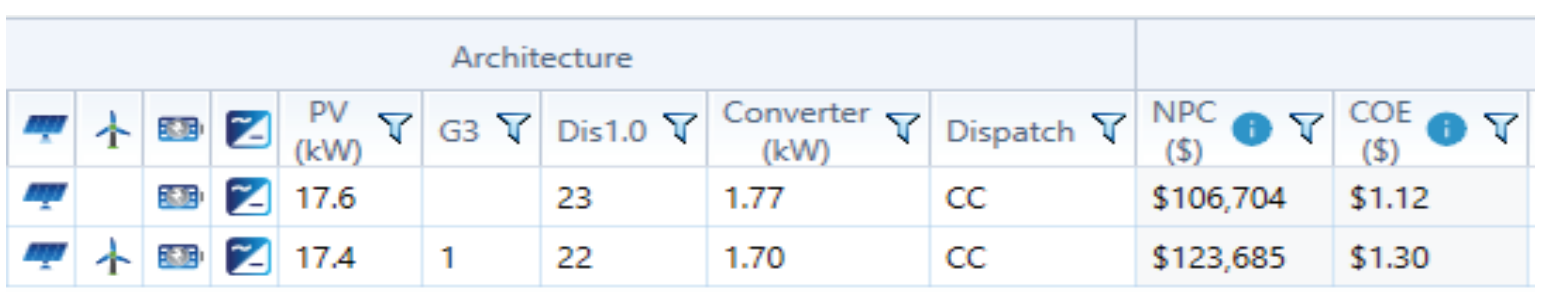

Gambar 10

Hasil simulasi konfigurasi mikrogrid PV-Turbin angin-Baterai untuk memenuhi kebutuhan beban AC \& DC di Laboratorium Teknik Tenaga Listrik

Program Studi Diploma III Teknologi Listrik UGM

Kedua, Konfigurasi mikrogrid PV-Turbin angin-Baterai untuk memenuhi kebutuhan beban AC

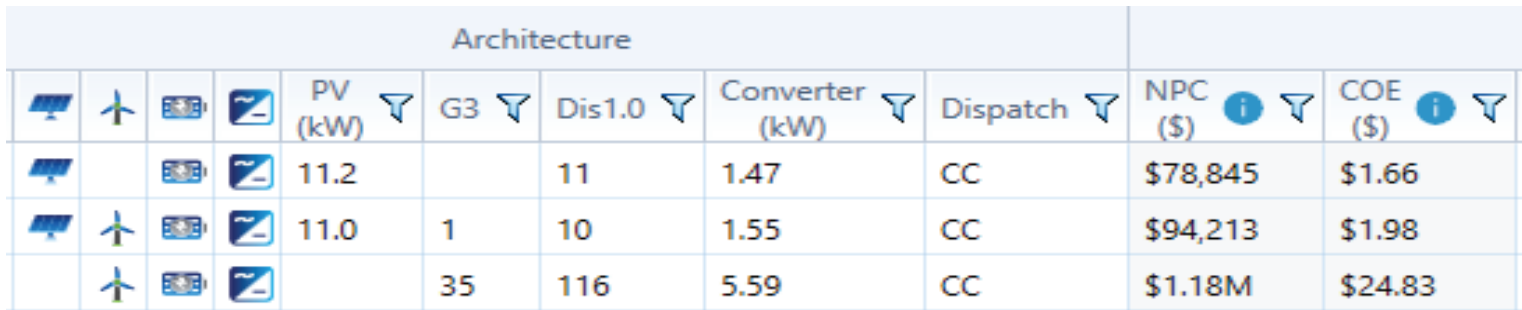

Gambar 11

Hasil simulasi konfigurasi mikrogrid PV-Turbin angin-Baterai untuk memenuhi kebutuhan beban AC di Laboratorium Teknik Tenaga Listrik

Program Studi Diploma III Teknologi Listrik UGM 
Berdasarkan Gambar 11, dapat ditunjukkan bahwa konfigurasi mikrogrid PV-Turbin angin-Baterai untuk memenuhi kebutuhan beban AC adalah PV-Baterai. Dengan konfigurasi tersebut, diperlukan biaya pembangkitan energi listrik $\$ 1,66 / \mathrm{kWh}$. Penggunaan generator turbin angin dalam

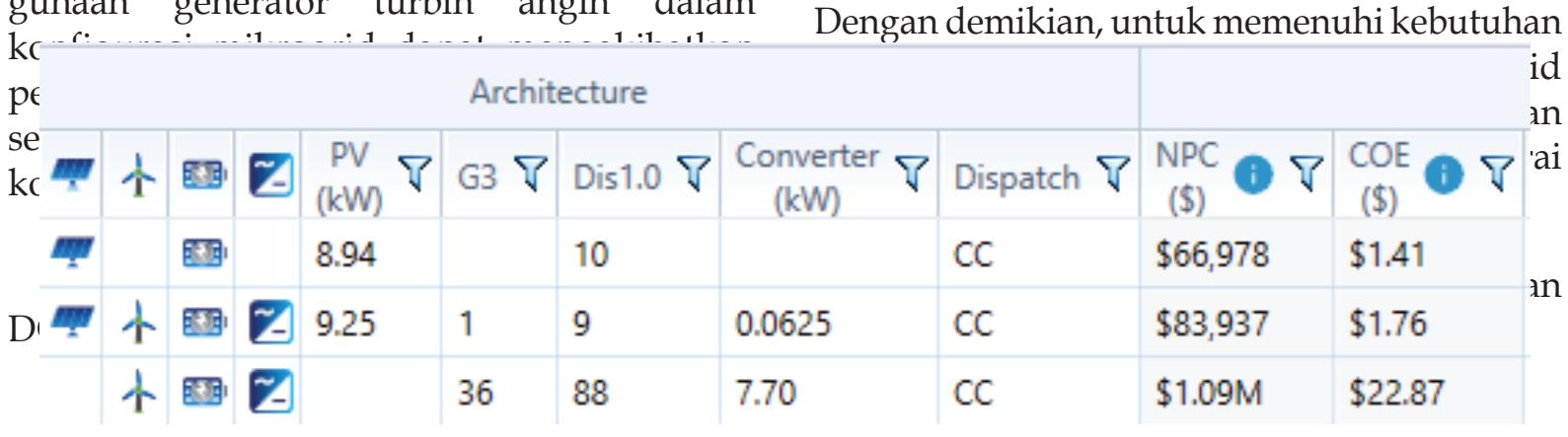

menyebabkan biaya pembangkitan energi listrik meningkat signifikan menjadi $\$ 24,83$. Dengan demikian, untuk memenuhi kebutuhan

Gambar 12

Hasil simulasi konfigurasi mikrogrid PV-Turbin angin-Baterai untuk memenuhi kebutuhan beban DC di Laboratorium Teknik Tenaga Listrik

Program Studi Diploma III Teknologi Listrik UGM

Berdasarkan Gambar 12, dapat ditunjukkan bahwa penggunaan konfigurasi mikrogrid PV-Turbin angin-Baterai untuk memenuhi kebutuhan beban DC adalah PV-Baterai. Dengan konfigurasi tersebut, diperlukan biaya pembangkitan energi listrik $\$ 1,41 / \mathrm{kWh}$. Sementara itu, pengintegrasian energi angin pada konfigurasi mikrogrid menyebabkan biaya pembangkitan energi listrik meningkat menjadi $\$ 1,76 / \mathrm{kWh}$. Sedangkan konfigurasi Turbin angin-Baterai

menyebabkan biaya pembangkitan energi listrik meningkat menjadi $\$ 22,87 / \mathrm{kWh}$. Dengan demikian, untuk memenuhi kebutuhan beban DC di Laboratorium Teknik Tenaga Listrik, Program Studi Diploma III Teknologi Listrik lebih ekonomis dipenuhi oleh mikrogrid dengan konfigurasi PV-Baterai.

Berdasarkan analisis pada konfigurasi mikrogrid PV-Turbin angin-Baterai untuk memenuhi kebutuhan beban praktikum di Laboratorium Teknik Tenaga Listrik, Program Studi Diploma III Teknologi Listrik, Departemen Teknik Elektro dan Informatika, Sekolah Vokasi UGM, konfigurasi mikrogrid PV-Baterai merupakan konfigurasi mikrogrid paling ekonomis dibandingkan PV-Turbin angin-Baterai maupun Turbin angin-Baterai. Selanjutnya, dengan membandingkan biaya pembangkitan energi listrik pada konfigurasi mikrogrid PV-Baterai untuk memenuhi ketiga alternatif pembebanan maka PV-Baterai yang digunakan untuk memenuhi kebutuhan beban AC \& DC lebih ekonomis dibandingkan konfigurasi mikrogrid PV-Baterai yang digunakan untuk memenuhi kebutuhan beban AC atau pun DC. Kondisi tersebut dapat terjadi karena terdapat korelasi positif antara potensi energi terbarukan, kapasitas konvertor energi dan kebutuhan beban. Produksi energi listrik berlebih tetapi tidak digunakan atau pun disimpan mengakibatkan biaya pembangkitan energi listrik semakin mahal.

\section{SIMPULAN}

Berdasarkan hasil analisis di atas, dapat disimpulkan bahwa konfigurasi mikrogrid PVTurbin angin-Baterai paling optimal digunakan untuk memenuhi kebutuhan energi listrik untuk beban AC dan DC. Pada konfigurasi mikrogrid tersebut, biaya pembangkitan energi listrik yang harus dibayarkan oleh pengguna adalah Rp 16.800,00/kWh.

Penelitian ini dilaksanakan sebagai rangkaian untuk menyusun modul pembelajaran praktikum di lingkungan Laboratorium Teknik Tenaga Listrik, Program Studi Diploma III Teknologi Listrik. Setelah 


\section{DHANIS WORO FITTRIN SELO NUR GIYATNO, LUKMAN SUBEKTI, DAN ADLAN BAGUS PRADANA \& OPTIMALISASI KAPASITAS ENERGI ANGIN DAN ...}

mendapatkan konfigurasi mikrogrid PV-Turbin angin-Baterai optimal, dapat dilanjutkan dengan melakukan asesmen untuk terhadap macam praktikum dan capaian pembelajaran yang dapat diperoleh.

\section{UCAPAN TERIMAKASIH}

Penelitian ini dilaksanakan dan dibiayai oleh Bantuan Pendanaan Perguruan Tinggi Badan Hukum Direktorat Penelitian Universitas Gadjah Mada Tahun Anggaran 2018 pada Peningkatan Kapasitas Peneliti Dosen Muda. Program tersebut diselenggarakan oleh Direktorat Penelitian Universitas Gadjah Mada 2018.

\section{DAFTAR PUSTAKA}

[1] D. Teknik Elektro dan Informatika, "Kurikulum D-III Teknologi Listrik," Departemen Teknik Elektro dan Informatika - Sekolah Vokasi Universitas Gadjah Mada, 2016.

[2] A. Zangeneh, S. Jadid, and A. R. Kian, "Promoting strategy of clean technologies in distributed generation expansion planning," Renew. Energy, vol. 34, no. 12, pp. 2765-2773, 2009.

[3] H. A. Gabbar, R. Islam, M. U. Isham, and V. Trivedi, "Risk-based performance analysis of microgrid topology with distributed energy generation," Int. J. Electr. Power Energy Syst., vol. 43, no. 1, pp. 13631375, 2012.

[4] R. Wardani, "Pemanfaatan Energi Terbarukan 'is a must,'" Direktorat Jenderal Energi Baru Terbarukan dan Konservasi Energi (EBTKE), 2018. .

[5] M. H. Hasan, W. K. Muzammil, T. M. I. Mahlia, A. Jannifar, and I. Hasanuddin, "A review on the pattern of electricity generation and emission in Indonesia from 1987 to 2009," Renew. Sustain. Energy Rev., vol. 16, no. 5, pp. 3206-3219, 2012.
[6] M. H. Hasan, T. M. I. Mahlia, and H. Nur, "A review on energy scenario and sustainable energy in Indonesia," Renew. Sustain. Energy Rev., vol. 16, no. 4, pp. 2316-2328, 2012.

[7] H. Firmansyah, Y. Tan, and J. Yan, "Power and methanol production from biomass combined with solar and wind energy: analysis and comparison," Energy Procedia, vol. 145, pp. 576-581, 2018.

[8] B. K. Sovacool, "Success and failure in the political economy of solar electrification: Lessons from World Bank Solar Home System (SHS) projects in Sri Lanka and Indonesia," Energy Policy, vol. 123, pp. 482-493, 2018.

[9] H. Outhred and M. Retnanestri, "Insights from the Experience with Solar Photovoltaic Systems in Australia and Indonesia," Energy Procedia, vol. 65, pp. 121-130, 2015.

[10] Y. Haroen, "Hydro, solar, and wind energy as potential electrical power plant in Indonesia - Past conditions and future prospects," 3rd Int. Conf. Inf. Technol. Comput. Electr. Eng. ICITACEE, pp. 1-1, 2016.

[11] F. Ardin, A. Rahardjo, and C. Hudaya, "Electricity price and subsidy scenario for hybrid power generations on off-grid system," Int. Conf. Control Electron. Renew. Energy Commun. ICCREC, pp. 132-138, 2017.

[12] Z. Ma et al., "Solutions for Remote Island Microgrids: Discussion and analysis of Indonesia's remote island energy system," IEEE Innov. Smart Grid Technol. - Asia ISGT Asia, pp. 493-498, 2018.

[13] A. J. Veldhuis, A. Nobre, T. Reindl, R. Ruther, and A. H. M. E. Reinders, "The influence of wind on the temperature of $\mathrm{PV}$ modules in tropical environments, evaluated on 
an hourly basis," IEEE 39th Photovolt. Spec. Conf. PVSC, pp. 0824-0829, 2013.

[14] I. N. S. Kumara, W. G. Ariastina, I. W. Sukerayasa, and I. A. D. Giriantari, "On the potential and progress of renewable electricity generation in Bali," 6th Int. Conf. Inf. Technol. Electr. Eng. ICITEE, pp. 1-6, 2014.

[15] B. F. Ronad and S. H. Jangamshetti, "Optimal cost analysis of wind-solar hybrid system powered AC and DC irrigation pumps using HOMER," Int. Conf. Renew. Energy Res. Appl. ICRERA, pp. 1038-1042, 2015.

[16] I. Elsayed, I. Nassar, and F. Mostafa, "Optimization and economic evaluation of small scale hybrid solar/wind power for remote areas in Egypt," Ninet. Int. Middle East Power Syst. Conf. MEPCON, pp. 2530, 2017.

[17] K. K. Jagtap, G. Patil, P. K. Katti, N. N. Shinde, and V. S. Biradar, "Techno-economic feasibility study of wind-solar PV hybrid energy system in Maharashtra state, India,"
IEEE Int. Conf. Power Electron. Drives Energy Syst. PEDES, pp. 1-5, 2016.

[18] S. Ghose, A. El Shahat, and R. J. Haddad, "Wind-solar hybrid power system cost analysis using HOMER for Statesboro, Georgia," SoutheastCon 2017, pp. 1-3, 2017.

[19] N. M. Swarnkar and L. Gidwani, "Economic and financial assessment of integrated solar and wind energy system in Rajasthan, India," Int. Conf. Comput. Power Energy Inf. Commun. ICCPEIC, pp. 471-476, 2017.

[20] Y. Zhou, M. Panteli, R. Moreno, and P. Mancarella, "Systemlevel assessment of reliability and resilience provision from microgrids," Appl. Energy, pp. 374392, 2018. 